\title{
Herminiimonas arsenicoxydans sp. nov., a metalloresistant bacterium
}

\section{Correspondence Marie-Claire Lett lett@gem.u-strasbg.fr}

\author{
Daniel Muller, ${ }^{1} \dagger$ Diliana D. Simeonova, ${ }^{1} \ddagger$ Philippe Riegel, ${ }^{2}$ \\ Sophie Mangenot, ${ }^{3}$ Sandrine Koechler, ${ }^{1}$ Didier Lièvremont, ${ }^{1}$ \\ Philippe N. Bertin ${ }^{1}$ and Marie-Claire Lett ${ }^{1}$
}

\begin{abstract}
An arsenite-oxidizing bacterium, designated strain ULPAs $1^{\top}$, was isolated from industrial sludge heavily contaminated with arsenic. Cells of this isolate were Gram-negative, curved rods, motile by means of a polar flagellum. The strain was positive for oxidase and catalase activities, was able to reduce nitrate to nitrite, used acetate, lactate and peptone as organic carbon sources under aerobic conditions and was able to oxidize arsenite (As[III]) to arsenate (As[V]). 16S rRNA gene sequence analysis and the absence of dodecanoic fatty acids suggested that this strain represents a member of the genus Herminiimonas of the family Oxalobacteraceae, order Burkholderiales in the Betaproteobacteria. Genomic DNA-DNA hybridization between strain ULPAs $1^{\top}$ and Herminiimonas fonticola S- $94^{\top}$ and between strain ULPAs $1^{\top}$ and Herminiimonas aquatilis CCUG $36956^{\top}$ revealed levels of relatedness of $<10 \%$, well below the recommended $70 \%$ species cut-off value. Thus, strain ULPAs $1^{\top}\left(=\mathrm{CCM} 7303^{\top}=\mathrm{DSM} 17148^{\top}=\mathrm{LMG} 22961^{\top}\right)$ is the type strain of a novel species of Herminiimonas, for which the name Herminiimonas arsenicoxydans sp. nov. is proposed.
\end{abstract}

The arsenic oxanion arsenite (As[III]) can be used by prokaryotes as an electron donor. Cells couple the oxidation of arsenite to the reduction of either oxygen or nitrate and use the energy derived either to fix $\mathrm{CO}_{2}$ into organic cellular material and achieve growth for chemolithoautotrophic prokaryotes or to help in the resistance to arsenic for heterotrophic organisms (Oremland \& Stolz, 2003). The microbiological oxidation of As[III] to arsenate (As[V]) impacts the mobility and the speciation of arsenic in the environment. More than 30 strains representing at least nine genera of the Bacteria and Archaea, including members of the Alphaproteobacteria, Betaproteobacteria, Gammaproteobacteria, Deinococcus-Thermus and Crenarchaeota, have been reported to be involved in arsenite oxidation.

tPresent address: Division of Bacterial Infection, Institute of Medical Science, University of Tokyo, 4-6-1, Shirokanedai, Minato-ku, Tokyo 108-8639, Japan.

$\ddagger$ Present address: Department of Biology, Laboratory of Ecology, Physiology and Biochemistry of Microorganisms, University of Konstanz, D-78457 Konstanz, Germany.

The GenBank/EMBL/DDBJ accession number for the 16S rRNA gene sequence of strain ULPAs $1^{\top}$ is AY728038.
Physiologically diverse, these micro-organisms include both heterotrophic arsenite oxidizers and chemolithoautotrophic arsenite oxidizers (Santini et al., 2000; Oremland \& Stolz, 2003; Silver \& Phung, 2005). Heterotrophic oxidation of As[III] is viewed primarily as a detoxification reaction that converts As[III] encountered on the outer membrane of the cell into the less toxic and less mobile form As[V], perhaps making it less likely to enter the cell (Anderson et al., 1992).

A Gram-negative, aerobic bacterial strain, designated ULPAs $1^{\mathrm{T}}$, was isolated from an industrial wastewater treatment plant contaminated with arsenic $\left(0.47 \mathrm{mmol} \mathrm{kg}{ }^{-1}\right)$ and other metals (Weeger et al., 1999). This strain was able to tolerate $5 \mathrm{mM} \mathrm{As}[\mathrm{III}]$ and was able to oxidize it to As[V] either in free suspension (Weeger et al., 1999; Muller et al., 2003) or immobilized in a calcium alginate gel (Simeonova et al., 2005). Moreover, strain ULPAs $1^{\mathrm{T}}$ was able to reduce $\mathrm{As}[\mathrm{V}]$ to $\mathrm{As}[\mathrm{III}]$ and to synthesize at least two arsenate reductases (Carapito et al., 2006). Finally, it was also found to be resistant to numerous heavy metals such as Se[IV], $\mathrm{Mn}[\mathrm{II}], \mathrm{Cr}[\mathrm{III}], \mathrm{Cd}[\mathrm{II}], \mathrm{Sb}[\mathrm{III}]$ and $\mathrm{Ni}[\mathrm{II}]$ (Muller et al., 2003). Based on partial 16S rRNA gene sequence analysis, strain ULPAs $1^{\mathrm{T}}$ was provisionally identified to be closely related to the species Duganella zoogloeoides (former Zoogloea 
ramigera IAM 12670) (Weeger et al., 1999) and was tentatively given the name 'Caenibacter arsenoxydans' (Carapito et al., 2006). The present study completes the phenotypic and genotypic characterization of this strain. Our results show that this bacterium represents a novel species of the recently described genus Herminiimonas (Fernandes et al., 2005).

Strain ULPAs $1^{\mathrm{T}}$ was isolated after aerobic enrichment on a chemically defined medium (CDM) supplemented with $1.33 \mathrm{mM}$ As[III] (Weeger et al., 1999). Briefly, CDM was prepared as follows: $100 \mathrm{ml}$ solution A $[81 \cdot 2 \mathrm{mM}$ $\mathrm{MgSO}_{4} .7 \mathrm{H}_{2} \mathrm{O}$ (Sigma), $187 \mathrm{mM} \mathrm{NH} \mathrm{NH}_{4} \mathrm{Cl}(99 \cdot 8 \%$ purity; Merck), $70 \mathrm{mM} \mathrm{Na} \mathrm{SO}_{4}$ (99\%; Prolabo), $0.574 \mathrm{mM}$ $\mathrm{K}_{2} \mathrm{HPO}_{4}$ (97\%; Prolabo), $4.57 \mathrm{mM} \mathrm{CaCl} 2.2 \mathrm{H}_{2} \mathrm{O}(99 \cdot 5 \%$; Merck), $446 \mathrm{mM}$ sodium lactate (98\%; Sigma)], $2.5 \mathrm{ml}$ solution $\mathrm{B}\left[4.8 \mathrm{mM} \mathrm{Fe} \mathrm{SO}_{4} .7 \mathrm{H}_{2} \mathrm{O}\right.$ (99\%; Prolabo)] and $10 \mathrm{ml}$ solution $\mathrm{C}$ [950 mM NaHCO 3 (99.5\%; Prolabo)] were mixed and made up to 1 litre with water. The final $\mathrm{pH}$ of the medium was about $7 \cdot 2$. Cells of strain ULPAs ${ }^{\mathrm{T}}$ were Gram-negative, and pale yellow to straw-coloured convex colonies with entire margins were observed when the strain was grown on CDM agar. Transmission electron microscopic observations showed that cells were slightly curved or straight rods with rounded ends, approximately $1-2.5 \mu \mathrm{m}$ long and $0 \cdot 5-0 \cdot 7 \mu \mathrm{m}$ wide, harbouring a single polar flagellum (Fig. 1). Cell motility was observed on low-concentration agar plates, with a swarming rate of $15-20 \mathrm{~mm}$ in $48 \mathrm{~h}$.

Different carbon substrates were tested and the results are listed in Table 1. Growth was not affected when the medium was supplemented with As[III] (1.3 mM). Chemolithoautotrophic growth was tested on CDM in the absence of lactate or other organic carbon sources; no growth was observed, indicating that strain ULPAs $1^{\mathrm{T}}$ possesses a chemoorganotrophic metabolism. Moreover, under anaerobic growth conditions (BBL GasPak pouch; Becton Dickinson) on

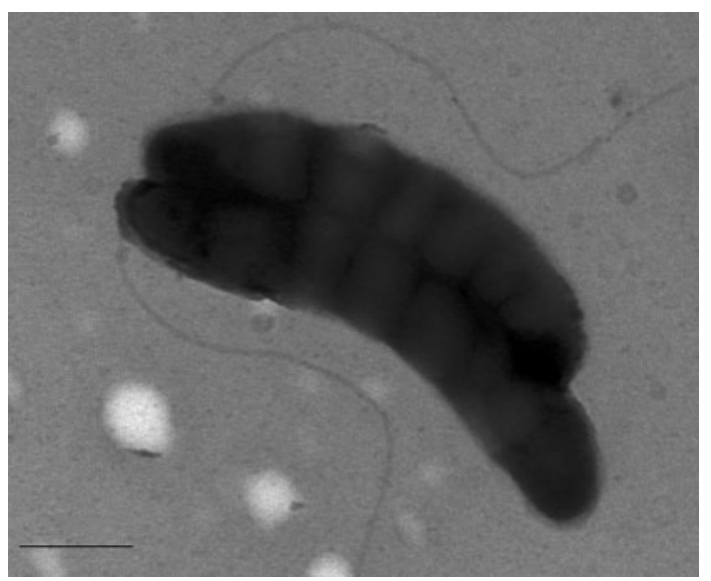

Fig. 1. Electron micrograph of a negatively stained cell of strain ULPAs $1^{\top}$, stained as described by Bertin et al. (1994). Bar, $500 \mathrm{~nm}$.
CDM containing a carbon source (lactate or acetate) and one metal ( $2.5 \mathrm{mM}$ selenate, $2.5 \mathrm{mM}$ arsenate), no growth was observed after 2 weeks, indicating that these metals are not used as electron acceptors. Finally, strain ULPAs $1^{\mathrm{T}}$ showed mesophilic growth between 4 and $30{ }^{\circ} \mathrm{C}$ with optimum growth at $25^{\circ} \mathrm{C}$. Above $30^{\circ} \mathrm{C}$, growth was inhibited. Optimum $\mathrm{pH}$ for growth was between 7 and $8 \cdot 5$. Antibiotic resistance was tested by the disc diffusion method (Courvalin et al., 1985). Growth of the isolate on CDM agar was not inhibited by tetracycline or ampicillin, but was inhibited by kanamycin, chloramphenicol, streptomycin and trimethoprim-sulfamethoxazol.

16S rRNA gene fragments were amplified by PCR from DNA extracts by using the eubacterial universal primers specific for this gene (P8: 5'-AGAGATTTGATCCTGGCTCAG-3'; Pc1544: 5'-AAGGAGGTGATCCAGCCGCA-3'). Phylogenetic analyses based on the 16S rRNA gene sequence (1455 nt) further supported the conclusion that the strain belongs to the Betaproteobacteria and that its nearest phylogenetic relatives are members of the family Oxalobacteraceae in the order Burkholderiales (Garrity et al., 2001): Herbaspirillum huttiense ATCC $14670^{\mathrm{T}}$ ( $96 \%$ sequence similarity), Herbaspirillum rubrisubalbicans ATCC $19308^{\mathrm{T}}(96 \%)$, uncultured Duganella clone CTHB-18 (96\%), Paucimonas lemoignei LMG $2207^{\mathrm{T}}$ (95\%), Duganella zoogloeoides IAM $12670^{\mathrm{T}}(94 \%)$ and Telluria mixta ACM $1762^{\mathrm{T}}(93 \%)$.

Strain ULPAs $1^{\mathrm{T}}$ exhibited $16 \mathrm{~S}$ rRNA gene sequence similarity of $98.56 \%$ to the recently described species Herminiimonas fonticola S-94 ${ }^{\mathrm{T}}$ (Fernandes et al., 2005), $98 \%$ to Herminiimonas aquatilis CCUG $44693^{\mathrm{T}}$ (Kämpfer et al., 2006) and $98.6 \%$ to the partially characterized strain ND5, isolated from a soil in Tokyo (Iizuka et al., 1998). A phylogenetic tree based on 16S rRNA gene sequences detailing the relationship between strain ULPAs $1^{\mathrm{T}}$ and its closest relatives is shown in Fig. 2. In order to determine further the position of strain ULPAs $1^{\mathrm{T}}$, DNA-DNA hybridization experiments were performed as described by Riegel et al. (1994). Strain ULPAs $1^{\mathrm{T}}$ showed levels of DNA-DNA hybridization of $3 \%$ with $H$. fonticola S- $94^{\mathrm{T}}, 5 \%$ with $H$. aquatilis CCUG $36956^{\mathrm{T}}$ and $11 \%$ with strain ND5. These values are clearly lower than the recommended $70 \%$ cut-off value used to delineate genomic species (Sneath, 1984; Stackebrandt \& Goebel, 1994).

Phenotypic data were obtained by classical methods of carbohydrate utilization determined either on nutrient broth or with the API 20NE and API 50CH systems. As with the two recently described Herminiimonas species, strain ULPAs $1^{\mathrm{T}}$ utilized few compounds as unique carbon sources, whereas strain ND5 was able to assimilate a greater variety of carbon sources (Table 1). H. aquatilis CCUG $36956^{\mathrm{T}}$ and strain ND5 have been shown to grow on nutrient-rich media (Iizuka et al., 1998; Kämpfer et al., 2006), but these media did not support the growth of strain ULPAs $1^{\mathrm{T}}$. The minimal inhibitory concentration (MIC) of different metals was determined by following the procedure described by Lim \& Cooksey (1993). Briefly, bacterial suspensions were 
Table 1. Physiological characteristics that differentiate strain ULPAs $1^{\top}$ and related strains

Strains: 1, strain ULPAs1 ${ }^{\mathrm{T}}$; 2, H. fonticola S-94 ${ }^{\mathrm{T}}$ (data from Fernandes et al., 2005); 3, H. aquatilis CCUG $44693^{\mathrm{T}}$ (Kämpfer et al., 2006); 4 , strain ND5 (data from this study unless indicated). With the exception of microscopic observations and metal resistance tests, all characteristics were tested by using the API $20 \mathrm{NE}$ and API $50 \mathrm{CH}$ systems for strains ULPAs1 ${ }^{\mathrm{T}}$ and ND5. Arsenite oxidase activity was tested by $\mathrm{AgNO}_{3}$ staining (Lett et al., 2001; Simeonova et al., 2004). All four strains are positive for oxidase activity and assimilation of lactate. Strains ULPAs $1^{\mathrm{T}}$ and ND5 showed negative results for glucose fermentation, aesculin hydrolysis, gelatin hydrolysis, $\beta$-galactosidase activity and assimilation of mannose, mannitol, $N$-acetylglucosamine, caprate, citrate, glycerol, erythritol, arabinose, D-ribose, xylose, methyl $\beta$-Dxylopyranoside, galactose, fructose, sorbose, L-rhamnose, dulcitol, inositol, D-sorbitol, amygdalin, arbutin, aesculin, salicin, D-cellobiose, D-maltose, D-lactose, D-trehalose, D-melezitose, starch, glycogen, xylitol, gentiobiose, D-turanose, D-lyxose, D-tagatose, fucose, arabitol, gluconate, 2-ketoglutarate and 5-ketoglutarate. +, Positive; -, negative; ND, no data.

\begin{tabular}{|c|c|c|c|c|}
\hline Characteristic & 1 & 2 & 3 & 4 \\
\hline Cell morphology & Curved rods & Rods & Rods & $\operatorname{Rods}^{*}$ \\
\hline Cell size $(\mu \mathrm{m})$ & $1-2 \times 0 \cdot 5-0 \cdot 7$ & $1-4 \times 0 \cdot 7$ & $3-4 \times 1-1 \cdot 5$ & $0 \cdot 5 \times 0 \cdot 1-0 \cdot 2^{*}$ \\
\hline Anaerobic growth & - & - & ND & - \\
\hline \multicolumn{5}{|l|}{ Growth temperature $\left({ }^{\circ} \mathrm{C}\right)$} \\
\hline Optimum $\mathrm{pH}$ for growth & $7 \cdot 2-8 \cdot 5$ & $8 \cdot 0$ & $\mathrm{ND}$ & $\mathrm{ND}$ \\
\hline DNA G $+C$ content $(\mathrm{mol} \%)$ & $54 \cdot 3$ & 52 & $\mathrm{ND}$ & ND \\
\hline \multicolumn{5}{|l|}{ MIC of metal ions: } \\
\hline $\mathrm{Cd}^{2+}$ & $630 \mu \mathrm{M}$ & $20 \mu \mathrm{M}$ & $80 \mu \mathrm{M}$ & ND \\
\hline $\mathrm{Mn}^{2+}$ & $>10 \mathrm{mM}$ & $10 \mathrm{mM}$ & $5 \mathrm{mM}$ & ND \\
\hline Nitrate reduction & + & - & $\mathrm{ND}$ & + \\
\hline Catalase & + & + & ND & + \\
\hline Indole production from tryptophan & - & - & $\mathrm{ND}$ & + \\
\hline Urease activity & - & - & $\mathrm{ND}$ & + \\
\hline \multicolumn{5}{|l|}{ Assimilation of: } \\
\hline Acetate & + & + & - & + \\
\hline Citrate & - & + & - & - \\
\hline Malate & - & + & - & + \\
\hline Phenylacetate & - & ND & - & + \\
\hline Adipate & - & $\mathrm{ND}$ & ND & + \\
\hline Gluconate & - & $\mathrm{ND}$ & - & + \\
\hline
\end{tabular}

${ }^{\star}$ Data from Iizuka et al. (1998).

transferred in triplicate from microtitre plates to solid CDM plates supplemented with increasing concentrations of metals. The MIC, defined as the metal concentration that inhibited confluent growth on plates after 3 days at $30^{\circ} \mathrm{C}$, was then determined (Table 1). Growth of $H$. fonticola, $H$. aquatilis and strain ND5 was inhibited by $2 \mathrm{mM}$ As[III], whereas strain ULPAs $1^{\mathrm{T}}$ exhibited growth at up to $5 \mathrm{mM}$ As[III]. Differences in MIC for different metals allowed the differentiation of ULPAs $1^{\mathrm{T}}$ from $H$. fonticola and $H$. aquatilis (Table 1). Taken together, these data demonstrate that, despite a significant level of conservation in their $16 \mathrm{~S}$ rRNA gene sequences, some significant phenotypic 


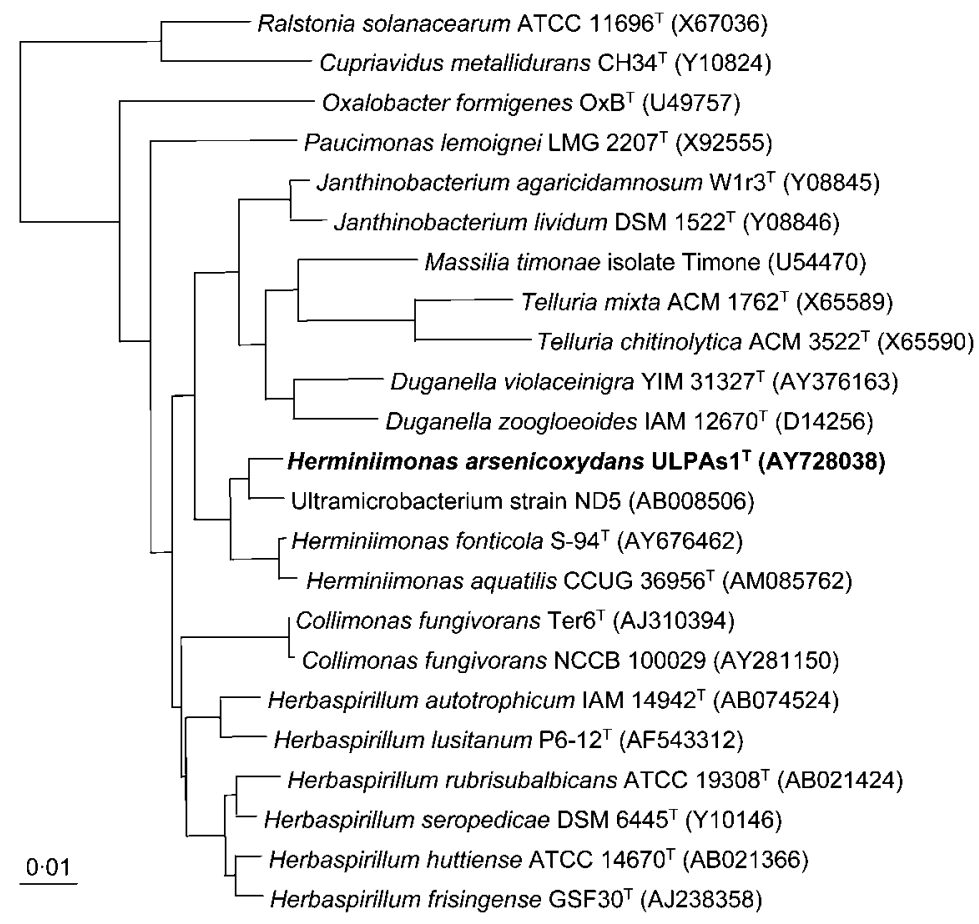

Fig. 2. Phylogenetic tree based on $16 \mathrm{~S}$ rRNA gene sequences, showing the relationship of strain ULPAs $1^{\top}$ with its closest relatives within the Oxalobacteraceae. The sequences obtained were compared with those in the EMBL/GenBank databases, and aligned by using the CLUSTAL method (Higgins \& Sharp, 1988) with DNAStar software. The $16 \mathrm{~S}$ rRNA gene sequence was aligned with reference sequences by using the CLUSTAL W program (Thompson et al., 1994). The tree was constructed from an evolutionary distance matrix calculated by the neighbour-joining method (Saitou \& Nei, 1987), with Cupriavidus metallidurans $\mathrm{CH} 34^{\top}$ and Ralstonia solanacearum ATCC $11696^{\top}$ as the outgroup. GenBank accession numbers are given in parentheses. Bar, 0.01 substitutions per nucleotide position.

differences allowed the differentiation of strain ULPAs $1^{\mathrm{T}}$ from $H$. fonticola, $H$. aquatilis and the partially characterized strain ND5 (Table 1).

Standard procedures were used to determine the $\mathrm{G}+\mathrm{C}$ content of the genomic DNA of strain ULPAs $1^{\mathrm{T}}$. The DNA $\mathrm{G}+\mathrm{C}$ content determined was $54.3 \mathrm{~mol} \%$, similar to the value for $H$. fonticola (52\%; Fernandes et al., 2005). Fatty acid analysis was performed by the Belgian Co-ordinated Collections of Microorganisms (BCCM ${ }^{\mathrm{TM}} / \mathrm{LMG}$, University of Gent, Belgium) and the results are presented in Table 2. The cellular fatty acid compositions of strain ULPAs $1^{\mathrm{T}}$, $H$. fonticola and $H$. aquatilis differ notably from those of other members of the 'Oxalobacteraceae' by the absence of dodecanoic fatty acids. As with $H$. fonticola and $H$. aquatilis, strain ULPAs $1^{\mathrm{T}}$ contained large amounts of $\mathrm{C}_{16: 0}$ and $\mathrm{C}_{16: 1} \omega 7 c$ fatty acids. Strain ULPAs $1^{\mathrm{T}}$ differed from $H$. aquatilis by producing $\mathrm{C}_{17: 0}$ cyclo and $\mathrm{C}_{14: 0}$. Differences in cellular fatty acid composition allowing the differentiation of strain ULPAs $1^{\mathrm{T}}$ from $H$. fonticola and $H$. aquatilis are shown in Table 2.

Taken together, our results suggest that strain ULPAs $1^{\mathrm{T}}$ is a member of the Betaproteobacteria, order Burkholderiales, and is the type strain of a novel species of the genus Herminiimonas, for which the name Herminimonas arsenicoxydans sp. nov. is proposed.

\section{Description of Herminiimonas arsenicoxydans sp. nov.}

Herminiimonas arsenicoxydans (ar.se.nic.ox'y.dans. N.L. n. arsenicum arsenic; N.L. v. oxydare to oxidize; N.L. part. adj. arsenicoxydans arsenic-oxidizing).
Cells are slightly curved or straight rods with rounded ends, approximately $1-2 \mu \mathrm{m}$ long and $0 \cdot 5-0 \cdot 7 \mu \mathrm{m}$ wide. Cells stain Gram-negative and harbour a single polar flagellum. Cells do not form spores. Colonies on CDM agar are convex with entire margins and are pale yellow to straw coloured.

Table 2. Fatty acid composition of Herminiimonas species

Strains: 1, strain ULPAs1 ${ }^{\mathrm{T}} ; 2, H$. fonticola $\mathrm{S}-94^{\mathrm{T}}$ (data from Fernandes et al., 2005); 3, H. aquatilis CCUG $44693^{\mathrm{T}}$ (Kämpfer et al., 2006). Data are percentages of total fatty acids.

\begin{tabular}{|lccc|}
\hline Fatty acid & $\mathbf{1}$ & $\mathbf{2}$ & $\mathbf{3}$ \\
\hline $\mathrm{C}_{9: 0}$ & - & - & $0 \cdot 2$ \\
$\mathrm{C}_{10: 0}$ & - & $0 \cdot 5$ & - \\
$\mathrm{C}_{10: 0} 3-\mathrm{OH}$ & 8 & $6 \cdot 0$ & $5 \cdot 2$ \\
$\mathrm{C}_{14: 0}$ & 5 & $4 \cdot 8$ & - \\
$\mathrm{C}_{15: 0}$ & - & - & $2 \cdot 8$ \\
$\mathrm{C}_{15: 1} \omega 6 c$ & - & - & $3 \cdot 6$ \\
$\mathrm{C}_{16: 1} \omega 7 c$ & $52 \cdot 7$ & $45 \cdot 6$ & $47 \cdot 7$ \\
$\mathrm{C}_{16: 1} \omega 5 c$ & - & $0 \cdot 8$ & $1 \cdot 5$ \\
$\mathrm{C}_{16: 0}$ & $20 \cdot 4$ & $26 \cdot 1$ & $11 \cdot 9$ \\
$\mathrm{C}_{17: 0}$ cyclo & $3 \cdot 3$ & $7 \cdot 9$ & - \\
$\mathrm{C}_{17: 1} \omega 6 c$ & - & - & $16 \cdot 0$ \\
$\mathrm{C}_{18: 1} \omega 7 c$ & $6 \cdot 6$ & $7 \cdot 3$ & $9 \cdot 1$ \\
$\mathrm{C}_{18: 0}$ & - & $0 \cdot 3$ & - \\
$\mathrm{C}_{19: 0}$ cyclo $\omega 8 c$ & - & $0 \cdot 4$ & - \\
Summed feature $6^{*}$ & $1 \cdot 5$ & - & - \\
\hline
\end{tabular}

${ }^{\star}$ Summed features represent groups of two or three fatty acids that cannot be separated by GLC with the MIDI system. Summed feature 6 comprises $\mathrm{C}_{18: 2} \omega 6,9 c$ and/or anteiso- $\mathrm{C}_{18: 0}$. 
Positive for oxidase and catalase activity. Most alcohols (e.g. ethanol, methanol), sugars (e.g. fructose, glucose) and sugar acids (e.g. gluconate) and most rich media (e.g. gelatin, trypticase soy, MRS and Luria-Bertani broths) do not support growth. Phototrophic or chemolithotrophic growth is not observed. Exhibits aerobic chemo-organotrophic metabolism using oxygen as a terminal electron acceptor. Optimal growth occurs at between $\mathrm{pH} 7$ and $8 \cdot 5$. Growth occurs at $4-30{ }^{\circ} \mathrm{C}$, optimal growth being at approximately $25^{\circ} \mathrm{C}$. Major fatty acids include $\mathrm{C}_{16: 0}, \mathrm{C}_{14: 0}$ and cyclo $\mathrm{C}_{17: 0}$. The hydroxylated fatty acid $\mathrm{C}_{10: 0} 3-\mathrm{OH}$ is also present but dodecanoic acid is not. Cells are resistant to tetracycline and ampicillin and to heavy metals: As[III] $(5 \mathrm{mM}), \mathrm{As}[\mathrm{V}]$ ( $>50 \mathrm{mM})$, Se[IV] $(>10 \mathrm{mM})$ and $\mathrm{Mn}[\mathrm{II}](>10 \mathrm{mM})$. Able to oxidize arsenite to arsenate as well to reduce arsenate to arsenite. The DNA G $+\mathrm{C}$ content is $54 \cdot 3 \mathrm{~mol} \%$.

The type strain, ULPAs $1^{\mathrm{T}}\left(=\mathrm{CCM} 7303^{\mathrm{T}}=\right.$ DSM $17148^{\mathrm{T}}=$ LMG $22961^{\mathrm{T}}$ ), was isolated from an enrichment culture inoculated with a liquid sample from an industrial wastewater treatment plant contaminated with arsenic in Germany.

\section{Acknowledgements}

The authors are grateful to Ajinomoto Co., Inc. (Kawasaki-ku, Japan) for providing strain ND5. We thank Peter Kämpfer for supplying H. fonticola S-94 ${ }^{\mathrm{T}}$ and Enevold Falsen for H. aquatilis CCUG $36956^{\mathrm{T}}$. Transmission electron microscopy analysis was performed at the microscopy platform of the Institut de Biologie Moléculaire des Plantes (IBMP-CNRS, Strasbourg), which is co-financed by CNRS, région Alsace, Université Louis Pasteur and the Association de la Recherche pour le Cancer. This work was performed within the framework of the 'Groupement de Recherche: Métabolisme de l'Arsenic chez les Prokaryotes' (GDR2909-CNRS).

\section{References}

Anderson, G. L., Williams, J. \& Hille, R. (1992). The purification and characterization of arsenite oxidase from Alcaligenes faecalis, a molybdenum-containing hydroxylase. J Biol Chem 267, 2367423682.

Bertin, P., Terao, E., Lee, E. H., Lejeune, P., Colson, C., Danchin, A. \& Collatz, E. (1994). The H-NS protein is involved in the biogenesis of flagella in Escherichia coli. J Bacteriol 176, 5537-5540.

Carapito, C., Muller, D., Turlin, E., Koechler, S., Danchin, A., Van Dorsselaer, A., Leize-Wagner, E., Bertin, P. N. \& Lett, M. C. (2006). Identification of genes and proteins involved in the pleiotropic response to arsenic stress in Caenibacter arsenoxydans, a metalloresistant beta-proteobacterium with an unsequenced genome. Biochimie (in press) doi:10.1016/j.biochi.2005.11.004

Courvalin, P., Goldstein, F., Philippon, A. \& Sirot, J. (1985). L'antibiogramme. Paris: MPC-Videom (in French).

Fernandes, C., Rainey, F. A., Nobre, M. F., Pinhal, I., Folhas, F. \& da Costa, M. S. (2005). Herminiimonas fonticola gen. nov., sp. nov., a betaproteobacterium isolated from a source of bottled mineral water. Syst Appl Microbiol 28, 596-603.
Garrity, G. M., Winters, M. \& Searles, D. B. (2001). Taxonomic outline of the prokaryotic genera. In Bergey's Manual of Systematic Bacteriology, 2nd edn, online release 1.0. New York: Springer.

Higgins, D. G. \& Sharp, P. M. (1988). CLUSTAL: a package for performing multiple sequence alignment on a microcomputer. Gene $\mathbf{7 3}$, 237-244.

lizuka, T., Yamanaka, S., Nishiyama, T. \& Hiraishi, A. (1998). Isolation and phylogenetic analysis of aerobic copiotrophic ultramicrobacteria from urban soil. J Gen Appl Microbiol 44, 75-84.

Kämpfer, P., Busse, H.J. \& Falsen, E. (2006). Herminiimonas aquatilis sp. nov., a new species from drinking water. Syst Appl Microbiol 29, 287-291.

Lett, M.-C., Paknikar, K. \& Lièvremont, D. (2001). A simple and rapid method for arsenite and arsenate speciation. In Biohydrometallurgy Fundamentals, Technology and Sustainable Development, part B, pp. 541-546. Edited by V. S. T. Ciminelli \& O. Garcia, Jr. Amsterdam: Elsevier.

Lim, C. K. \& Cooksey, D. A. (1993). Characterization of chromosomal homologs of the plasmid-borne copper resistance operon of Pseudomonas syringae. J Bacteriol 175, 4492-4498.

Muller, D., Lièvremont, D., Simeonova, D. D., Hubert, J. C. \& Lett, M. C. (2003). Arsenite oxidase aox genes from a metal-resistant beta-proteobacterium. J Bacteriol 185, 135-141.

Oremland, R. S. \& Stolz, J. F. (2003). The ecology of arsenic. Science 300, 939-944.

Riegel, P., de Briel, D., Prévost, G., Jehl, F. \& Monteil, H. (1994). Genomic diversity among Corynebacterium jeikeium strains and comparison with biochemical characteristics and antimicrobial susceptibilities. J Clin Microbiol 32, 1860-1865.

Saitou, N. \& Nei, M. (1987). The neighbor-joining method: a new method for reconstructing phylogenetic trees. Mol Biol Evol 4, 406-425.

Santini, J. M., Schnagl, R. D., Macy, J. M. \& Sly, L. I. (2000). A new chemolithoautotrophic arsenite-oxidizing bacterium isolated from a gold mine: phylogenetic, physiological, and preliminary biochemical studies. Appl Environ Microbiol 66, 92-97.

Silver, S. \& Phung, L. T. (2005). Genes and enzymes involved in bacterial oxidation and reduction of inorganic arsenic. Appl Environ Microbiol 71, 599-608.

Simeonova, D. D., Lièvremont, D., Lagarde, F., Muller, D. A. E., Groudeva, V. I. \& Lett, M.-C. (2004). Microplate screening assay for the detection of arsenite-oxidizing and arsenate-reducing bacteria. FEMS Microbiol Lett 237, 249-253.

Simeonova, D. D., Micheva, K., Muller, D. A. E., Lagarde, F., Lett, M.-C., Groudeva, V. I. \& Lièvremont, D. (2005). Arsenite oxidation in batch reactors with alginate-immobilized ULPAs1 strain. Biotechnol Bioeng 91, 441-446.

Sneath, P. H. A. (1984). Numerical taxonomy. In Bergey's Manual of Systematic Bacteriology, vol. 1, pp. 5-11. Edited by N. R. Krieg \& J. G. Holt. Baltimore: Williams \& Wilkins.

Stackebrandt, E. \& Goebel, B. (1994). Taxonomic note: a place for DNA-DNA reassociation and 16S rRNA sequence analysis in the present species definition in bacteriology. Int J Syst Bacteriol 44, 846-849.

Thompson, J. D., Higgins, D. G. \& Gibson, T. J. (1994). CLUSTAL W: improving the sensitivity of progressive multiple sequence alignment through sequence weighting, position-specific gap penalties and weight matrix choice. Nucleic Acids Res 22, 4673-4680.

Weeger, W., Lièvremont, D., Perret, M., Lagarde, F., Hubert, J. C., Leroy, M. \& Lett, M. C. (1999). Oxidation of arsenite to arsenate by a bacterium isolated from an aquatic environment. Biometals 12, 141-149. 